\title{
Depression and Screening Cardiovascular Events
}

\author{
Kim G. Smolderen, Annelies E. Aquarius, and Johan Denollet \\ CORPS-Center of Research on Psychology in Somatic diseases, Department of Medical Psychology, Tilburg University, Tilburg, The Netherlands.
}

To the Editor: - Peripheral arterial disease (PAD) remains an under-treated disease ${ }^{1}$, and information about risk factors and prognosis is poorly disseminated in the population ${ }^{2}$. Nevertheless, PAD and coronary artery disease (CAD) patients share the same risk factors, and risks of future cardiovascular events in PAD patients are comparable with those in CAD patients ${ }^{3}$. Depression may adversely impact prognosis in CAD patients ${ }^{4}$, but little is known about depression and prognosis in PAD. Therefore, we read with great interest the work of Cherr and colleagues ${ }^{5}$ on the relation between psychological factors and cardiovascular events in PAD. Their study generated interesting findings, but there are also a number of issues we would like to address here.

First, the screening method the authors used probably led to an overestimation of depression rates. The General Health Questionnaire is not a depression scale, but rather was developed to assess non-specific psychological distress in community samples ${ }^{6}$, and a higher cut-off score $(\geq 8)$ has been recommended to screen for depressive symptoms in patients with chronic somatic disease ${ }^{7}$.

Second, $80 \%$ of depressed patients received antidepressant therapy. Analyses were not adjusted for type of antidepressant, while studies warn against the use tricyclic antidepressants in cardiovascular populations because they are associated with an increased risk of myocardial infarction ${ }^{8,9}$. Therefore, we cannot rule out the influence of antidepressant use on adverse outcomes in depressed patients.

Finally, in the adjusted analyses, only a rough parameter of disease severity was included (indication for intervention). Table 2 shows us that the group that underwent revascularization was very heterogeneous in terms of disease severity; indication for intervention ranged from claudication to critical leg ischemia and gangrene or tissue loss. It would have been more appropriate to include the lowest ankle-brachial index in the adjusted analyses due to its strong prognostic value for adverse cardiovascular events in $\mathrm{PAD}^{10}$. Likewise, in CAD, the relation between depression and increased risk of mortality seems to be confounded by cardiac disease severity or left ventricular dysfunction ${ }^{11}$. Future studies examining the link between psychological factors and prognosis in PAD need to take into account reliable indices of disease severity.

Open Access This article is distributed under the terms of the Creative Commons Attribution Noncommercial License which

Published online July 16, 2008 permits any noncommercial use, distribution, and reproduction in any medium, provided the original author(s) and source are credited.

Johan Denollet, CoRPS-Center of Research on Psychology in Somatic diseases, Department of Medical Psychology, Tilburg University, Tilburg, The Netherlands (e-mail: J.Denollet@uvt.nl).

\section{REFERENCES}

1. Belch JJ, Topol EJ, Agnelli G, Bertrand M, Califf RM, Clement DL, et al. Critical issues in peripheral arterial disease detection and management: a call to action. Arch Intern Med. 2003;163(8):884-892.

2. Hirsch AT, Murphy TP, Lovell MB, Twillman G, Treat-Jacobson D, Harwood EM, et al. Gaps in public knowledge of peripheral arterial disease: the first national PAD public awareness survey. Circulation. 2007;116(18):2086-2094.

3. A randomised, blinded, trial of clopidogrel versus aspirin in patients at risk of ischaemic events (CAPRIE). CAPRIE Steering Committee. Lancet 1996;348(9038): 1329-1339.

4. van Melle JP, de Jonge P, Spijkerman TA, Tijssen JG, Ormel J, van Veldhuisen DJ, et al. Prognostic association of depression following myocardial infarction with mortality and cardiovascular events: a metaanalysis. Psychosom Med. 2004;66(6):814-822.

5. Cherr GS, Zimmerman PM, Wang J, Dosluoglu HH. Patients with depression are at increased risk for secondary cardiovascular events after lower extremity revascularization. J Gen Intern Med. 2008;23(5):629-634.

6. Pevalin DJ. Multiple applications of the GHQ-12 in a general population sample: an investigation of long-term retest effects. Soc Psychiatry Psychiatr Epidemiol. 2000;35(11):508-512.

7. Härter M, Woll S, Wunsch A, Bengel J, Reuter K. Screening for mental disorders in cancer, cardiovascular and musculoskeletal diseases. Comparison of HADS and GHQ-12. Soc Psychiatry Psychiatr Epidemiol. 2006;41(1):56-62.

8. Cohen HW, Gibson G, Alderman MH. Excess risk of myocardial infarction in patients treated with antidepressant medications: association with use of tricyclic agents. Am J Med. 2000;108(1):2-8.

9. Zellweger MJ, Osterwalder RH, Langewitz W, Pfisterer ME. Coronary artery disease and depression. Eur Heart J. 2004;25(1):3-9.

10. Feringa HH, Bax JJ, van Waning VH, Boersma E, Elhendy A, Schouten O, et al. The long-term prognostic value of the resting and postexercise ankle-brachial index. Arch Intern Med. 2006;166(5):529535.

11. van Melle JP, de Jonge P, Ormel J, Crijns HJ, van Veldhuisen DJ, Honig A, et al. Relationship between left ventricular dysfunction and depression following myocardial infarction: data from the MIND-IT. Eur Heart J. 2005;26(24):2650-2656

J Gen Intern Med 23(9):1543

DOI: $10.1007 / \mathrm{s} 1$ 1606-008-0696-8

(C) The Author(s) 2008 